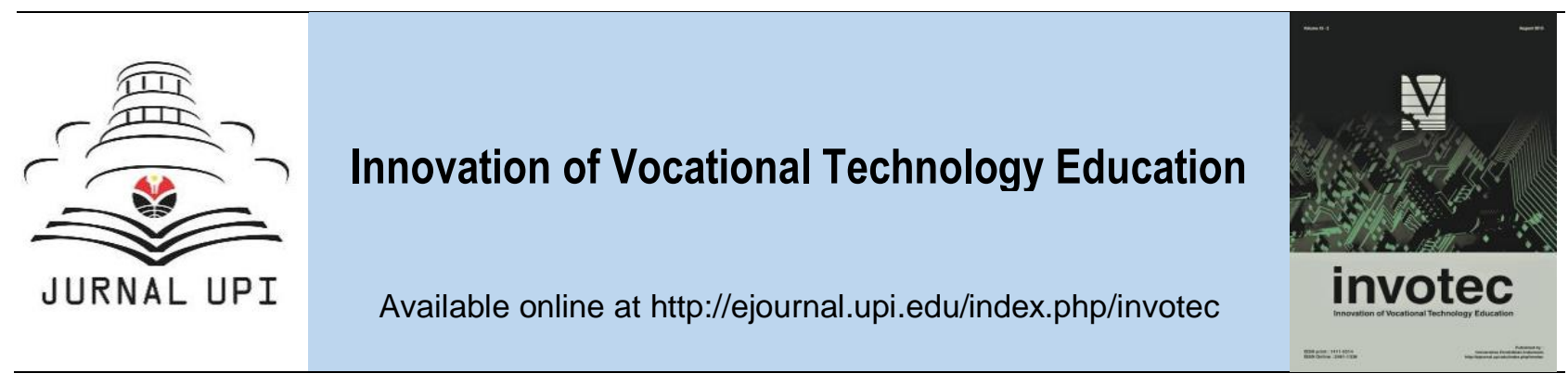

\title{
Computer-Mediated Discourse Analysis as Language Teaching Material: An Assessment of Exploration for Students Develop Democratic Character
}

\author{
A. R. Shaifullahh \\ Universitas Pendidikan Indonesia, Indonesia
}

\section{ARTICLE INFO}

\section{Article history:}

Received 2 October 2017

Received in revised form 30 October

2017

Accepted 15 November 2017

Available online 28 February 2018

Keywords:

Computer-mediated discourse,

Teaching material,

Democratic character

Corresponding author:

arshaifullahh@upi.edu

\author{
A B S T R A C T
}

\section{Introduction}

At the beginning, it as a communication tool, but the function of language does not stop there (Shaifullah, 2013). The development of sophisticated language study looked almost directly proportional to the development technology (Lim, 2005; Herring, 2004 \& 2011), the political constellation (Huntington, 1996; Rumbled \& Chen, 2015), economic growth (Diamond, 1999; Jackson, 2005).), and socio-cultural dynamics (Crystal, 2006; Dahlberg, 2006; Hoed, 2014). This phenomenon has encouraged the study of linguistics in interdisciplinary position. The linguist began talk about the function of language as a shaper of reality, even beyond the limits of reality, called hyper reality (Franke, 2012). Language itself has a protective function (Etienne, 2015). Languages can be used as imaging tool (West, 2015). Language can even change the situation (Cutting, 2008). Special studies the language associated with the development of Internet technology and the widespread of communications users in the virtual space, Hoed (2014:279)) called the process democratization encourage structural change of mentality from the top down to dialogue, while Van Dijk (2009: 209) referred to it as the phenomenon of democratization and increasing participatory culture.

If so sit his case, in the context of language learning in schools, appearing question: whether interactive discourse on the Internet can be used as teaching materials in language learning in the classroom to develop students' democratic character? Use interactive discourse on the Internet as 
a language teaching materials, in the form of text news and text responses contained in cyber media, this exploratory study tries to answer the question. The goal, to show the role of linguistic studies in an attempt interdisciplinary development model of language learning in the context of Indonesian society post-reform who are eager to realize the democratic values in everyday life, nation and state. Focused on Huntington (1996:6), which referred to basic values of democracy is equality of relations of power and freedom expression and expression.

The theory of discourse in the perspective of Foucault (1982 \& 2010) used in this study to see indicators of power relations that occur in the text of the news and media response text in cyberspace as teaching materials supposedly containing potentially democratic values. Question Michel Foucault that fundamental filed with respect to discourse is: how discourse produced and what is the effect of the production of discourse? According to him, the discourse is not just a series of words or propositions in the text, but further than that: the discourse is something that producing others, may be an idea, a concept, or effect.

Therefore, according to him, the discourse be detected systematically as an idea, opinion, concept, and view of life is formed in a particular context that influence the way of thinking and the act of a person. Foucault argues that through discourse, one or a group of people, can realize the power, which is used to beat the other. Therefore, Foucault defines discourse operationally as stage power struggles, which tends asymmetric (unequal), which effects on the meaning of hegemony by the dominant or ruling.

Theory of Herring (2011) on a computer-mediated discourse or known CMD used in this study to look at the context of the media and the context of the communication situation in the practice of discourse in cyber media. According to him, understanding interactive discourse in the context of CMD is the characteristic effects of computer technology to the use of language, as the embodiment of a social practice, so the traits and characteristics contained in a computer media and Internet channels attached also on the characteristics and interactive discourse. The characteristics are: interactivity, demassification, asynchronous and simultaneous. What is meant by interactivity is the ability Internet technology has an interactive feature that connects the media with users and inter-fellow users. What is meant by demassification is Internet technology capabilities in terms of range of audiences in the number and stage almost endless. There was simultaneous asynchronous and are two concepts that contain understanding of different, even opposite. Internet technology can be used to interact at the same time the so-called simultaneous, or with a difference time called asynchronous.

\section{Method}

Three news texts and 77 texts responses contained in the cyber media analyzed to see meaning the discourse related to power relations (Foucault 1982, 2010) and the process discourse of relating to media context and the context of the communication situation (Herring 2011). Text message and the response text contained in the most popular cyber media in Indonesia version Alexa international media survey organizations (Sways \& Dina, 2013), namely detik.com. Cyber media selection on the basis of popularity, while the selection of the theme of terrorism is regarded as the actual issue and tend controversialist (Aitchison 2003; Chomsky \& Bersanian, 2005; Hodges \& Nile, 2007; Altheide, 2007; Adi, 2010).

The analysis process is done in several stages, in accordance with the procedures and techniques suggested by text analysis method Grounded Theory (Strauss \& Corbin, 1990), namely: the coding phase open (open coding), the coding phase cross (axial coding), and the coding phase of elected (selective coding). At the stage of open coding, verbal elements of each text news and text responses described and sought meaning in a way browse through word by word and sentence by sentence to be able to find the key words that form proposition, which is the smallest unit of meaning and assertive (simple) in discourse analysis (Fairclough, 2001; Renkema, 2004). The results of this open coding became the foundation for the next stage of the analysis axial coding. At this stage, the analysis of the similarities and differences between propositions media and proposition responders conducted to determine the extent of the struggle of meaning place in the media cyber-indicators reflected in the indicators in the form of signs verbal language. The findings of the indicators that are used as a foothold in analysis. Next, the encoding chosen, the categorization about interactive discourse as democratic teaching materials based on the verbal signs contained in the report text and text responses. 


\section{Result and Discussion}

The results of the analysis of the similarities and differences between the signs and the meaning of media and responders (Table 1), which is intended to measure the tendency of the similarities and differences between the media and responders. Based on the results of calculation of the similarities and differences of meaning between the media and responders, , it can be stated that the responders tend to refute the opinion developed by media through verbal signs such as text news comes from a statement resources.

Table 1. Similarities and differences in signs and meanings between media and responders

\begin{tabular}{|c|c|c|c|}
\hline Similarities & $f: X=Y$ & Differences & $f: X><Y$ \\
\hline $\begin{array}{l}\text { X1): Build opinion, with statements } \\
\text { by observers, that terrorist acts } \\
\text { Boom JW Marriott and Ritz Carlton } \\
\text { related to the } \\
2009 \text { presidential election }\end{array}$ & $\mathrm{X} 1=\mathrm{Y} 1, \mathrm{Y} 2, \mathrm{Y} 3$ & $\begin{array}{l}\text { Acts of terrorism "Boom } \\
\text { Kininogen II" is not related to the } \\
2009 \text { presidential }\end{array}$ & $\mathrm{X} 1><\mathrm{Y} 4-\mathrm{Y} 11$ \\
\hline $\begin{array}{l}\text { X2): Build opinion, with statements } \\
\text { by observers, that acts of terrorism } \\
\text { allegedly linked to the group } \\
\text { Nordine Metope }\end{array}$ & $\mathrm{X} 2=\mathrm{Y} 15, \mathrm{Y} 16$ & $\begin{array}{l}\text { Acts of terrorism are not linked } \\
\text { with the group Nordine Metope }\end{array}$ & $X><Y 17$ \\
\hline $\begin{array}{l}\text { X3) Build opinion, with statements } \\
\text { by observers, that acts of terrorism } \\
\text { "Boom Kininogen II" linked } \\
\text { Islamization. }\end{array}$ & $X 3=Y 18-Y 36$ & $\begin{array}{l}\text { Acts of terrorism "Boom } \\
\text { Kininogen II" is not linked } \\
\text { Islamization }\end{array}$ & $X 3><Y 37-Y 74$ \\
\hline $\begin{array}{l}\text { X4) Build opinion, with statements } \\
\text { by observers, that acts of terrorism } \\
\text { only trouble makers }\end{array}$ & $X 4=1$ & $\begin{array}{l}\text { Acts of terrorism not just trouble } \\
\text { makers }\end{array}$ & $X 4><1$ \\
\hline $\begin{array}{l}\text { X5) Build opinion, with statements } \\
\text { by observers, that the terrorist } \\
\text { group is not linked with the issue of } \\
\text { people's poverty Indonesia }\end{array}$ & $\times 5=2$ & $\begin{array}{l}\text { The terrorist group linked to the } \\
\text { issue of poverty the people of } \\
\text { Indonesia }\end{array}$ & $X 5><2$ \\
\hline $\begin{array}{l}\text { X6) Build opinion, with statements } \\
\text { by observers, that terrorism is not } \\
\text { associated with the US strategy of } \\
\text { Neo-Liberalism and Neo-Capitalism }\end{array}$ & $X 6=5$ & $\begin{array}{l}\text { Build opinion, with statements } \\
\text { by observers, that acts of } \\
\text { terrorism associated with the } \\
\text { strategy of the United States of } \\
\text { Neo-Liberalism and Neo- } \\
\text { Capitalism }\end{array}$ & $X 6><2$ \\
\hline
\end{tabular}

${ }^{*} \mathrm{f}: \mathrm{X}=\mathrm{Y}$ : shows the frequency of similarities between $\mathrm{X}$ (media) and $\mathrm{Y}$ (responders)

${ }^{*} \mathrm{f}: \mathrm{X}><\mathrm{Y}$ : shows the frequency difference between $\mathrm{X}$ (media) and $\mathrm{Y}$ (responders)

Proposition responders and the media look the same, because responders tend to support that acts of terrorism allegedly linked to the group Nordine M. Top (Y16, Y17) and the United States conspiracy strategy (Y76, Y77, Y78) as opinions constructed by the media (X2 and X6) via verbal signs that contain a resource statement (T2). Opinion want built media that acts of terrorism allegedly linked to the group Nordine M. Top (X2) and the United States conspiracy strategy (X5), awakens in the mind of the responders (Y16 and $Y 17)$ and (Y76, Y77, Y78). Information sent successfully trigger responder's media to express her response, because most expressing support response and rebuttal responses, as well as smaller reveals an ambiguous response. Although using only a single speaker, but there responders who looked at the positive truth and credibility of information sources.

Proposition responders and propositions media seem different, because responders tend to argue that acts of terrorism allegedly linked to the Presidential Election (Y4 so Y12), and Islamization (Y24 up to Y61) as opinions constructed by the media (X1 and $\mathrm{X} 3$ ) through signs verbal containing a resource statement (T1 and T3). Responders tend to view the issue of terrorism expressed by the media and declared a resource that acts of terrorism allegedly linked to the Presidential Election (X1) as an expression of support for an observer to the authorities shortsighted (Y11), pinhead (Y9), less intelligent and feel oppressed (Y8), inconsequential and spoiled (Y10), oblique and misguided (Y12). All of this adds, according to responders, intended to show resentment and disappointment (Y8) by way of pitting (Y4) and mutual slander (Y5), which boils down to an attempt of political engineering in order to gain public sympathy imaging (Y8). 
Responders tend to view the issue of terrorism which media disclosed on the statement of a resource that acts of terrorism associated with the movement of Islamization (X3) as saying: crazy thought (Y50) ancient (Y56), discredit one religion (Y67), cornering a particular party (Y43), a little bit associated with Islam (Y64, and look at Islam from one side (Y68); expressed with as good belly (Y54), not use thought (Y61), rash (Y41), inconsequential (Y42, Y47), make hot ears (Y63), eccentric (Y66), and wind (Y53); coming from an observer ridiculous (Y62), weird (Y65), bastard (Y46), provocateurs true (Y49), damned (Y48), unclean panatela (Y52), the hero oversleep (Y51), too dumb (Y58), brain washed by Baking (Y61), the mastermind of the event (67), and cat litter (Y55); intended to find names (Y40), seeking sympathy (Y43), the Christianization of the foreign party (Y45), slander and make chaos (Y57).

Media only uses a single speaker and not reliable in view responders to build an opinion, whereas responders tend to view negative sources used by the media, both with regard to the accuracy of information (trust) and in terms of the level of credibility. Opinion wanted to build a media that acts of terrorism associated with the presidential and Islamization (X1 and X3) are not awakened in the minds of the responders (Y4 sod Y12) and (Y24 Y61). The diversity of views on the opinion responders to be built by the media contained in the Data 1 detik.com not only related with the intent to support, denied, or ambiguous (Table 1), but also with regard to the weight of the truth of the information (trust) and the credibility of sources of information and media. The responders tend to look negatively on the truth and credibility of information and media resources. The following propositions show it. Proposition that showed negative responses to the credibility of sources of information: This as not A Team Nordine M Top, Where possible Islamization, the Islamic revolution fuck cat! Islamic revolution? hahahahhaaahhhh ancient, between faiths who make the mess, definitely the accused terrorist Muslims, not associated with islam you see only one side of islam. Nothing to do with politics and election. Negative response to the speaker's credibility: analyst bastard, provocateurs, observers silly, make hot ears, strange observer, a US ally, former Intelligent oblique, mastermind to discredit one religion, origin jeeplike wrote, by the use of American intelligence brain! terrorist, Islam is rahmatan lil 'alamin. Don't generalize offender with Religion, inconsequential comments, observers strange. Credibility negative response media: resources, he was too stupid.

This study shows how the reader response to texts that are constructed in the discourse of interactive media on the Internet plays an important role in facilitating the aspirations of debate and dissemination of information are expected to contribute to the democratization process in this country. The diversity of the response text direction is an indicator of the democratization process in the news cyberspace media discourse.

(R)
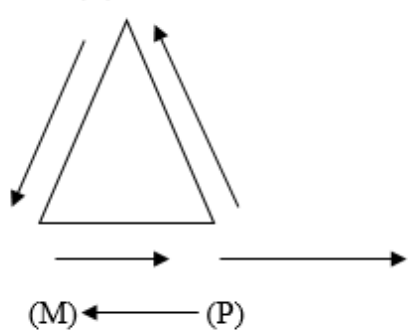

(S) $\quad(\mathrm{M})$

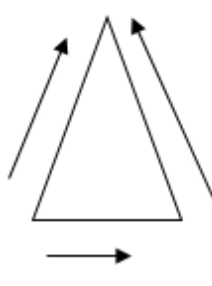

(P) $\longleftarrow(\mathrm{P})$

Note: $(\mathrm{R})$ Resources; $\mathrm{M}=$ Media; $\mathrm{P}=$ Responders

Figure 1. Process discourses in cyber media (Shaifullah 2016: 307)

Figure 1 shows that the direction of the response was that there were addressed to the media (M), resources $(S)$, and fellow-responders $(P)$. Interactions between $P$ and $S$ is two-way (dialogue) but do not deal because he said follow mediated by the media. Interactions between $\mathrm{P}$ and $M$ is two-way (dialogue) and the face (face to face), in the sense of sending a text message $M$ to $P$, then $P$ responded to the news sent by $M$. interaction unsustainably, with no response from $M$ to P. Interactions between $\mathrm{P}$ and $\mathrm{P}$ lasted multidirectional (debate), face to face, and continues.

Rests on Herring (2011), analysis of the interactions in this study relates to factors context of media and communication situational context factors. There is no relationship analysis with regard to the concept of Foucault (2010) on the dominant power relationships and determinants in the 
practice of discourse. Analysis of this interaction consists of two parts: a media context factors and factors of the context of the communication situation. In general, the results of the analysis of the interaction based media context factors.

Table 2. Classification of media context factors (Shaifullah 2016: 307)

\begin{tabular}{|c|c|c|c|}
\hline Code & Dimensions & Category & Notes \\
\hline M1 & synchronicity & synchronized & $\begin{array}{l}\text { Because the messages stored on the } \\
\text { recipient site responders, to be read later by } \\
\text { anyone. }\end{array}$ \\
\hline M2 & $\begin{array}{l}\text { Message } \\
\text { transmission }\end{array}$ & $\begin{array}{l}\text { Message by } \\
\text { Message, one way }\end{array}$ & $\begin{array}{l}\text { Because it considers not engage } \\
\text { simultaneously with the receiver. }\end{array}$ \\
\hline M3 & $\begin{array}{l}\text { Transcript } \\
\text { persistence }\end{array}$ & long time Stored & $\begin{array}{l}\text { Text responses relatively longer survive in } \\
\text { the cyber media sites, enabling the recipient } \\
\text { and / or other responders participated }\end{array}$ \\
\hline M4 & Message size & unlimited & $\begin{array}{l}\text { The number of characters available in cyber } \\
\text { media for reader response is not restricted }\end{array}$ \\
\hline M5 & $\begin{array}{l}\text { communication } \\
\text { channels }\end{array}$ & textual & No load pictures, video, audio \\
\hline M6 & $\begin{array}{l}\text { anonymous } \\
\text { message }\end{array}$ & $\begin{array}{l}\text { Is more dominated } \\
\text { by anonymous } \\
\text { message }\end{array}$ & Responders are using pseudonyms \\
\hline M7 & personal message & $\begin{array}{l}\text { Is more dominated } \\
\text { by private message }\end{array}$ & $\begin{array}{l}\text { Subjective opinions addressed to the growing } \\
\text { opinion in the media }\end{array}$ \\
\hline M8 & censorship & Cannot be detected & $\begin{array}{l}\text { Typography is not standard can be an } \\
\text { indicator of the low level of censorship }\end{array}$ \\
\hline M9 & quotation & $\begin{array}{l}\text { Referring to the text } \\
\text { of the news }\end{array}$ & $\begin{array}{l}\text { Most responses referring to the text of the } \\
\text { news }\end{array}$ \\
\hline M10 & message format & $\begin{array}{l}\text { chronologically } \\
\text { formatted }\end{array}$ & Sorted by hour, day, date, and year. \\
\hline
\end{tabular}

The first factor relates to the media factor is the dimension of synchronicity (Table 2), i.e., continuity or in continuity relationship. In the case of reader response in cyber media, what happens is the asynchronous system, because it does not require users recorded at the same time to send and receive messages, but the messages stored on site until they can be read receiver. In a synchronous system, otherwise, the sender and receiver must be logged in simultaneously, such as mode of real-time as chatting is the most common form of the form of communication through computers in sync.

This synchronicity is a predictor dimension and a strong indicator of the complexity of discourse structure, associated with pragmatic and interactional behavior in discourse through a computer. The emergence of harsh rebuttal that tend to be rough and insulting in the examples following responses can be identified as a pragmatic behavior made possible by the media context factors that are not face to face or synchronicity.

In general, the results of correlation analysis based on factors the context of the communication situation shown in the following Table 3 . The dimensions of structures of participation refers to the number of participants in the communication situation in cyber media (whether actual, i.e., active participation, and potential), the number and level of participation (impressionistic or quantitative), whether public communication, semi-private, or private, the extent to which the other person chooses to interact anonymously, whether rough uneven participation, or whether some individual or group dominates. The structure of this participation has implications for, among other things, on the level of politeness.

Based on the results of the above analysis it can be said that the dynamics of meaning among responders about the issue of terrorism which are constructed media if they see the diversity of interpretations of the responders to the media representation and diversity of interpretation responders with representation fellow responders. This was seen when the responders expressing support, denial, or ambiguous attitude towards the media representation, as well as a debate among responders. The dynamics of meaning between responders and the media and among the responders can be used as indicators of the democratization process in cyber media, relating to freedom of expression and expression. The results of the analysis of signs and meanings between the media and among responders and responders showed it. 
Table 3. Classification of the communication situation (Shaifullah, 2016: 308)

\begin{tabular}{|c|c|c|c|}
\hline Code & Dimensions & Category & Notes \\
\hline S1 & $\begin{array}{l}\text { The structure of } \\
\text { participation }\end{array}$ & Personal to public & Unlimited number responders \\
\hline S2 & $\begin{array}{l}\text { The characteristics } \\
\text { of participants }\end{array}$ & Ideologically various & Based on media ideology \\
\hline S3 & Purpose & $\begin{array}{l}\text { Comment on information, } \\
\text { opinion }\end{array}$ & $\begin{array}{l}\text { Topic development related to } \\
\text { public issue accurse }\end{array}$ \\
\hline S4 & Theme/topic & Politics/terrorism & "Kininogen bomb 2" \\
\hline S5 & Tone & $\begin{array}{l}\text { Serious but relaxed, tend to } \\
\text { be emotional }\end{array}$ & $\begin{array}{l}\text { Mixed, more serious ones, less } \\
\text { relaxed ones }\end{array}$ \\
\hline S6 & Activities & $\begin{array}{l}\text { Responding to news text and } \\
\text { debating to other responders }\end{array}$ & $\begin{array}{l}\text { Confrontative and tend to be } \\
\text { sarcastic }\end{array}$ \\
\hline S7 & Norm & informal & $\begin{array}{l}\text { Tend to exaggerate, rude, and } \\
\text { insulting }\end{array}$ \\
\hline S8 & Language code & Casual & Tend to use informal language \\
\hline
\end{tabular}

In the case (Table 1), through the analysis of mean verbal signs and meanings contained in the text of the responders, it was found that a small percentage responders tended to support media information to be built, while the majority of responders tend to refute the information that you want built media. Efforts to offset the dominance of media by responders in defining terrorism successfully if seeing the many sources of information and opinion purpose to be built partially on to the media responders. This was seen when the responders tend not interpret verbal signs sent by the media as desired by the media. Only a small portion responders understand the information on the issue of terrorism as intended by the media. This is evident from the support responders to information on the issue of terrorism as intended by the media, namely, the issue of terrorism was linked to the 2009 Presidential election, Nordine M. Tope group, islamization, and the conspiracy of the United States. Most responders tend not to understand information about the issue of terrorism as intended by the media. This is evident from the rebuttal responders to information about terrorism as intended by the media. According to responders, the issue of terrorism was not linked to the presidential election, the group Nordine M. Top, islamization, and the conspiracy of the United States, but associated with short-term political interests of the ruling party in the context of the political situation after the presidential election, that the efforts of political imagery, looking for sympathy, diversion issues, and pit-sheep. Responders tend to look negatively on the credibility of the informant and the media as well as the validity of information disclosure. It was seen when the media uses only a single speaker and not reliable in view responders to build an opinion, whereas responders tend to view negative sources used by the media, both with regard to the accuracy of information (trust) and in terms of the level of credibility.

Responders successfully use the virtual space cyber media on the Internet as a stage to express his thoughts and feelings associated with regard to the issue of terrorism which is constructed by the media. This is evident from the pattern of interaction in cyber media which tends to be centered on responders and relationships that tend to be dominated by responders. The success of responders in using virtual space cyber media on the Internet can be an indicator of the democratization process related to patron-client principle of equality in democratic life. The results of analysis of the pattern of interactions and relationships between responders and the media and among the responders showed it.

In the case (Table 1), the interaction that occurs between responders and the media takes place in one direction in one episode: of responders to the media, without any response from the media. This is evident from signs contained in the verbal text and text media responders. Interactions that occur among responders are two-way and can occur in a few episodes. This is evident from signs contained in the verbal text responders. In addition to the media and fellow responders, interaction also occurs between media and sources of information in one direction: from the responders to the resources, without addressors of resources. Power relations that occur between responders and the media and between responders and resources take place in three types of power relations: dominant, equal, determinants. Responders tend to dominate the media when it denied the information about the issue of terrorism which was built media. Responders tend to be equivalent to the media when an ambiguous or neutral attitude towards the issue of terrorism is built media. Responders tend determinant (dominated by the media) when the supporting information on the issue of terrorism which was built media. 
This study shows how the reader response to texts that are constructed in the discourse of interactive media on the Internet plays an important role in facilitating the aspiration -the debate and dissemination of information- are expected to contribute to the democratization process in the country, and more specifically, to build understanding more balanced about the issue of terrorism. In this study the meanings of signs verbal about the issue of terrorism which is constructed by the media explored by examining the responses of Internet users to the opinions to be built by a variety of resources (President, observers and politicians) through the medium of cyber inform the issue of terrorism with respect to events bomb Kininogen 2. From the analysis conducted meaning it can be seen that the propositions are constructed media use verbal signs based on opinions and resources. The results of the analysis of the proposition shows that the meaning is trying constructed by the media on the issue of terrorism relies on a statement of official information source authorities, namely the President, who suspected that an act of terrorism boom Kininogen 2 was associated with those who disappointed in the results of the 2009 presidential election that won him and partner. While the resources of the intelligence analysts who tend to favor official statement of resources by the authorities seek to develop opinions on the issue of terrorism as also related to the group Nordine M. Top, islamization and the conspiracy that he believed the United States as far as the growing opinion in the middle community. While other sources of information, from among politicians, in this case Prabowo, felt that the alleged authorities and observer's intelligence was addressed to him, and therefore he tried to develop opinions through the media that terrorism was not at all related to the Presidential Election 2009, let alone by itself as one of the candidates for vice president.

Analysis of the propositions responders showed that responders tended to vary in response to various statements on the issue of terrorism resources built by the media. Meaning diversity among the responders was an indication the dynamics of meaning among the public regarding the issues of terrorism, constructed by the media by the ruling elite resources and politicians. Based on the analysis purposes, it can be concluded that diversity responder's proposition that there are three different types of speech acts expressed by responders through verbal signs contained in the text of the response. First, the speech act responders tended to support the purpose to be constructed by the media. Second, the speech act responders who denied any intention to be built by the media. Third, the speech act responders ambiguous (does not clearly indicate support or denial). The analysis shows that there are responders tend to be fully denied, there is a balance between supporting and denied, and there are fully supportive statements resources built by the media.

The results of the analysis of propositional showed that signs of verbal contained in the text responders addressed to the intent that want to build media was that the terrorism issue was related to the presidential election, boils down to the proposition image politics, efforts to seek public sympathy, and engineering intelligence. While the media proposition stating that terrorism was associated with the movement of islamization, tended to by responders with the proposition of pitting, scapegoat and discredit certain religious groups.

The results of the analysis show the significance of the interaction and relationships between the media and responders in just one stage / episode, while responders place in several episodes. Thus, there is a debate between media and responders. The debate occurs only among responders. Thus, the phenomenon of the process of semiosis word of mouth, as found by Hoed (2014) in a study of semiotics of advertising, there is also in the process of discourse on the Internet.

The results of the analysis of the similarities and differences of signs and meanings also showed that the responses of Internet users have to do with the truth and credibility of the information and media resources. Responders tend to see that level of accuracy associated with truth information was low and doubted, because, according to the responders, information which was built by the media only by single source of information and more is an attempt for sympathy as part of the image politics and engineering intelligence. Responders also tended to see that the level of credibility of information sources is low and dubious, because, in the view of responders, all the resources that have a track record poor in the past.

Based on the findings above, it can be concluded that the cyber media virtual space on the Internet can be formulated as a democratic forum if viewed freedom of expression and expression and equality of power relations can take place in a friendly and flexibility for Internet users. The hospitality is evident in the context of the cyber media as an open arena for anyone to interpret 
reality constructed by the media. While the flexibility shown in the context of the communication situation that is free at any time to make a response to the report text.

Based on these results alone, in fact inadequate to ensure the factors that cause the differences of meaning between responders and the media, let alone projected it to come to the conclusion with regard to the role of the Internet as a forum for democratization. Many variables have not been fully revealed by this study: for example, related to social cognition and ideology. However, there are a number of subtle cues that the characteristics of the technology and media used in the process of interactive discourse on the Internet that helps determine and be one factor in the democratization process in cyber media.

Previous research on the role of the Internet as a forum for democratization by using sociological data relating to political behavior (Lim, 2005, Dalberg, 2006) has concluded that Internet users, with content characteristic of friendly, tend to feel more free and autonomous in expressing an idea or an opinion compared with using conventional media, because the Internet provides a kind of stage for the less dominant actor to use this technology without being controlled by dominant actors. Meanwhile, the study results Hoed (2014) put forward his thesis on the process of democratization through cyberspace encouraging change the structure, from the top down to dialogue.

While this study produce different portraits in the field of study, perspectives and contextspecific, so finding a new hypothesis regarding the role of the Internet as a forum for democratization. In addition to the hospitality (conviviality), flexibility (discretion) can apparently be used as keywords to appoint one of the characteristics of the technology and Internet media in relation to the behavior and the discourse that takes place in the media cyber, which refers to the state of the technology and media Internet and user behavior are likely to be open, free and independent. In the category developed by Huntington (1996), Ohlin (1997), and McLuhan (1998), indicators of freedom of expression, openness of expression, and equality of power relations was included in the concept of formal democracy. While concerning indicators of the concept of substantive democracy, which includes rationality, tolerance (Diamond, 1999), and wisdom (Gunarwan, 2007) seems not yet materialized, because the results of this study indicate that how to speak responders is still very much dominated by the vocabulary/phrases are charged higher emotions expressed by way of excess, tend to be rough and contain elements of insult. thus, democracy and democratization process, which is classically understood as government of the people, by the people, for the people, which described in concise and packed by Huntington (1996) in his monumental work. Third Wave of Democratization, as something that continues wave, in the context of language use on the Internet and within certain limits already realized formally, but not yet materialized substantially.

Relating to the thesis Hoed (2014) which indicated a change in the structure of power relations patron-client from the top down to dialogue, the research produces different hypothesis. Structural changes do occur in the process of democratization in the virtual space cyber media, but not completely top down to dialogue. The results of this study show that was going on here is a change in the structure of power relations are reversed: from the top down to bottom up. Public will no longer be a determinant of the ruling party which tends to be dominant, but the public so those who dominate the party in power. This is evident from the results of this study indicate that the responders so freely direct response to the media and information sources, while media and resources such as do not have the space to respond to feedback from Internet users. Thus, the dialogue does not occur between the responders and the media. What happens is a dialogue among responders. This phenomenon can be identified as hyper-democratization, which is a process of democratization that is centered on a public that tends to approach the behavior of anarchy.

As is known, the responder is defined traditionally as a receiver or consumer of discourses, which react or perform in accordance with the responses referred to by the shipper or manufacturer of discourse (Renkema, 2004). The results of this analysis show different things. In the context of interactive discourse on the Internet's role responders tend to be shifted to consumers as well as producers of discourse (produce men), with one of the markers is the expansion of the agenda or topics relating to the theme of terrorism. Terrorism, which is commonly defined as an act of politically-motivated violence and power with the aim of spreading terror and fear both psychologically and physically to the public (Chomsky and Bersanian, 2005), text reader response has led a variety of speculation associated with action-motivation or background the 
violence. Starting from the thesis of clash of civilizations (Huntington, 1996), the death of democracy (Altheide, 2007), explosive movement Islamic fundamentalism (Jackson, 2005, Hodges, 2007), until the thesis blowback and McTeror (Nye, 2004; Egloff, 2015) which describes the unintended consequences of the aggressive policies of the hidden and the militarization of the United States.

While a single case study does not provide a sound basis for formulating generalizations about the process of democratization in the Internet, the practical implications of this research is, in particular, the discovery of alternative media that can be used as a discourse stage process more democratic. In other words, in practice, this research useful because it shows the existence of alternative media that can accommodate the public interest in the process of meaning in a more equal, fair, interactive, and produce men (combined point of view of producers and consumers).

\section{Conclusion}

In the context of interactive discourse on the Internet, the process does not purport to reality again dominated by the media and/or authorities, but had to share with the public as Internet user. The phenomenon of the diversity of this concept can be used as guidance that interactive discourse on the Internet can be used as an arena for realizing the basic values democracy relating to freedom of expression and expression. In the context of interactive discourse on the Internet, the process takes place in a format discourse dialogue and bottom-up, so that the power relationship between the media and respondents take place in symmetrical pattern or equivalent. The phenomenon of the equity in the process of this discourse can be used as a hint that the interactive discourse on the Internet can be used as a stage for embodies the basic values of democracy with regard to freedom of expression opinions.

\section{References}

Adi, B.T. 2010. Critical Discourse Analysis (CDA) of terrorism in Newsweek magazine: Uncovering connections between language, ideology and power. Saarbrucken: Lambert Academic Publishing.

Aitchison, J. 2003. From Armageddon to war: The vocabulary of terrorism. In J. Aitchison \& D.M. Lewis (eds), New media language. London: Routledge.

Altheide, D.L. 2007. The mass media and terrorism. Discourse \& Communication 1(3): 287-308.

Chomsky, N. \& Bersanian, D. 2005. Imperial ambitions: Conversations on the post-9/11 world. New York: Metropolitan Books.

Crystal, D. 2006. Language and the Internet. Cambridge: Cambridge University Press.

Cutting, J. 2008. Pragmatics and discourse. New York: Routledge.

Dahlberg, L. 2006. Computer-Mediated Communication and the Public Sphere: Acritical analysis. Journal of ComputerMediated Communication 7.

Diamond, L. 1999. Developing democracy toward consolidation. Baltimore: The John Hopkins University Press.

Egloff, G. 2015. Violence prevention and beyond-Theses on the spirit of terrorism. Egyptian Journal of Forensic Sciences 5: 75-78.

Etienne, A.DE. 2015. The flow of time and the flow of signs: A basis for Peirce's. The American Journal of Semiotics 31(1/2).

Fairclough, N. 2001. Language and power. New York: Longman.

Foucault, M. 1982. The order of discourse. In M. Shapiro (ed.), Language and Politics. Oxford: Blackwell. 
Foucault, M. 2010. The archeology of knowledge and the discourse of language. New York: Vintage Book Edition.

Franke, M. 2012. On assertor and directive signals and the evolution of dynamic meaning. International Review of Pragmatics 4(2): 232-260.

Gunarwan, A. 2007. Pragmatik: Teori dan kajian nusantara. Jakarta: Universitas Atmajaya.

Herring, S.C. 2004. Computer-Mediated Discourse. In D. Tannem, D. Schiffrin \& H. Hamilton (eds), Handbook of Discourse Analysis: 612-634. Oxford: Blackwell.

Herring, S.C. 2011. A Faceted Classification Scheme for Computer-Mediated Discourse. Bloomington: Indiana University Press.

Hodges, A. \& Nile, C. 2007. Discourse, war and terrorism. Colorado: John Benyamin's Publishing Company.

Hoed, B.H. 2014. Semiotik \& dinamika social budaya (2 ${ }^{\text {nd }}$ Ed.). Jakarta: Komunitas Bambu.

Huntington, S.P. 1996. The Third Wave Democratization in the Late Twentieth Century. London: University of Oklahoma Press.

Jackson, R. 2005. Writing the war on terrorism: Language, politics and counter terrorism. Manchester University Press: Oxford.

Lim, M. 2005. @archipelago online: The Internet and political activism in Indonesia (Unpublished Dissertation). University of Twente, Netherland.

McLuhan, M. 1998. War and peace in the global village. New York: Gingko Press.

Nye Jr., J.S. 2004. Soft power: The means to success in world politics. New York: Public Affairs.

Ohlin, A. 1997. Indonesia and the "Third Wave Democratization": The Indonesian pro-democracy movement in a changing world. London: Curzon Press.

Renkema, J. 2004. Discourse studies: An introductory textbook. Amsterdam/Philadelphia: John Benjamin Publishing Company.

Rumbled, G. \& Chen, H. 2015. Advice-giving in newspaper weather commentaries. Journal of Pragmatics 89: 14-30.

Shafiullah, A.R. 2013. Wacana Interaktif di Internet sebagai Bahan Ajar bahasa: Studi Penjajagan Menuju Pembelajaran bahasa yang Demokratis. Prosiding Seminar Internasional Linguistik Transdisipliner, Departemen Linguistik, Fakultas IImu Pengetahuan Budaya Universitas Indonesia, Kampus UI Depok, Senin, 2 Desember 2013.

Shafiullah, A.R. 2016. Issues of terrorism on the Internet in the new wave of democratization of [post-reform Indonesia. Indonesian Journal of Applied Linguistics 5(2): 306-314.

Strauss, A. \& Corbin, J. 1990. Basics of qualitative research: Grounded theory, procedure and technique. London: SAGE Publications.

Sways, R.F. \& Dina, B. 2013. Mapping Digital Media: Jordan a report by the open society foundations. Country report. https://www.opensocietyfoundations.org/ses/default/ files/mapping-digital-media jordan-20131121.pdf.

Van Dijk, T. 2009. Society and discourse: How social context influence text and talk. Cambridge: Cambridge University Press.

West, D.E. 2015. The work of soundness as habit in the development of early schemes. Public Journal of Semiotics 6(2): 1-13. 